Article

\title{
The Importance of Philanthropic Corporate Social Responsibility and Its Impact on Attitude and Behavioral Intentions: The Moderating Role of the Barista Disability Status
}

\author{
Jinsoo Hwang ${ }^{1}{ }^{\mathbb{D}}$, Jinkyung Jenny Kim ${ }^{2, *} \mathbb{D}$ and Seokhoon Lee ${ }^{1}$ \\ 1 The College of Hospitality and Tourism Management, Sejong University, 98 Gunja-Dong, Gwanjin-Gu, \\ Seoul 143-747, Korea; jhwang@sejong.ac.kr (J.H.); esukun1987@gmail.com (S.L.) \\ 2 School of Hotel and Tourism Management, Youngsan University, 142 Bansong Beltway, Busan 48015, Korea \\ * Correspondence: jennykim1120@gmail.com
}

Received: 6 July 2020; Accepted: 30 July 2020; Published: 3 August 2020

check for updates

\begin{abstract}
Despite the increased attention to corporate social responsibility and employment of disabled people worldwide, there is insufficient evidence about the effect of these interrelated initiatives on the formation of consumer behavior. To fill this gap, this study was designed to understand consumers' responses with respect to such activities in the coffee industry. More specifically, this study proposed that philanthropic corporate social responsibility (PCSR) aids to enhance attitude which subsequently increases behavioral intentions. In addition, this study examined the moderating role of barista disability status in the relationship between PCSR and attitude. The quantitative approach was used to examine hypotheses, and data were collected from the following two types of Starbucks: (1) Starbucks where disabled baristas provide services and (2) Starbucks where non-disabled baristas provide services. The results of data analysis showed that PCSR positively affects attitude, which in turn has a positive influence on intentions to use, word-of-mouth intentions, and willingness to pay more. Lastly, the moderating role of barista disability status was identified. Based on the findings, discussions involved theoretical and managerial implications of this study that include the encouragement of hiring people with disabilities in the coffee shops.
\end{abstract}

Keywords: philanthropic corporate social responsibility; attitude toward using a brand; intentions to use; word-of-mouth intentions; willingness to pay more; barista disability status

\section{Introduction}

Over a billion people live with some form of disability, which represents almost 15 percent of humanity in the globe [1]. Persons with disabilities are individuals who have long-term physical, mental, intellectual, or sensory impairments [2]. Such individuals face various barriers that restrict them from participating in a local community or a larger society on an equal basis with others $[1,2]$. Particularly, the disabled are considered as the world's largest minority in the labor market [3]. With this respect, unceasing efforts were made to promote the concept of equal opportunities and increase the hiring of those with disabilities. Likewise, many governments established the regulations or quota systems to take the employment rate for the disabled to the next level $[4,5]$. However, the results are not inspiring. According to the disability employment report issued by the U.S. Department of Labor Bureau of Labor Statistics, employment-population ratios in 2019 are 19.3 percent and 66.3 percent for persons with a disability and without a disability, respectively [6]. The latest data from Labor Force Survey (LFS) indicated that the employment rate for disabled people in 2019 was 53.2 percent and that for non-disabled people was 81.8 percent in the United Kingdom [7]. The employment rate gap 
between the disabled and non-disabled is even larger in the service industry, where many sources reported employment rate for people with disabilities in service encounter positions as far below the average [8-10]. These statistics confirm that there is a lot of room for improvement in the employment for people with disabilities in the hospitality sector.

The role of corporation is not limited to create private value for its shareholders but also creates public value for the larger economy, namely society [11-14]. Following this notion, corporate social responsibility (hereafter CSR) was built on the concept of creating shared value [11,12]. CSR was accordingly defined as "a commitment to improve community well-being through discretionary business practices and contributions of corporate resources" [15]. The significance of CSR has grown over the decades and now, it is nearly a requisite for every business entity throughout the world $[12,13]$. In other words, corporations in the modern society are under more pressure to look after the community in a socially responsible way. Likewise, a number of companies in the field of hospitality have initiated diverse CSR programs. In the coffee industry, Starbucks is one of the great examples which engaged with various CSR initiatives [16-18]. The company takes the lead in developing a variety of CSR activities such as energy and water conservation, reuse and recycling, and financial support to the farmers [16]. The program called "C.A.F.E." (Coffee and Farmer Equity) illustrated how Starbucks Coffee Company is in collaboration with the non-profit organization to improve environmental and social measures in coffee cultivation [17].

CSR programs are classified into diverse sets such as economic, legal, ethical, and philanthropic, or philanthropy, value chain, and ecosystem [12,14]. Among them, philanthropic CSR (hereafter PCSR) involves proactive engagement in activities or programs to promote human well-being or goodwill [12]. In this respect, hiring disabled people is considered as a good deed in the area of PCSR since it responds not only to good faith but to the expectation of current society's needs [9,13]. In addition, Pino et al. [19] asserted that PCSR activities are more easily noticed by consumers, and thus they are more relevant to the formation of consumers' attitude and intention. For this reason, the present study is centered on PCSR engaged in the employment of people with disabilities.

Following the growing CSR activities in the service industry, scholars began to test the impact of these CSR practices on consumers' responses [18-20]. Attitude has been one of the popular constructs as a result of CSR programs, and CSR was examined as one of the crucial predictors of consumer attitude toward a certain company or a brand [19-23]. These researchers articulated a significant link between social initiatives and positive affective and cognitive responses (i.e., attitude). For example, companies initiating various CSR programs were perceived as more compassionate, more ethical, trustworthy and warmer $[18,19,21]$. That is, studies have provided the sufficient evidence that a company's CSR practices improve brand evaluation and corporate image. More importantly, engaging in PCSR was proven to be beneficial to create more favorable consumer attitude towards using a brand in many studies $[13,19,20]$. On the other hand, attitude toward using a brand has been found to be a strong indicator of consumers' behavioral intentions (i.e., intentions to use, word-of-mouth intentions, and willingness to pay more) $[19,24,25]$. In this regard, our study aimed to test the influence of PCSR on consumer attitude toward using a brand and, subsequently, on behavioral intentions in the coffee industry context. Additionally, the current research focused on barista disability status in light of limited evidence in the existing literature despite the attempts at identifying the moderating impact of disability status in other settings [26,27].

In this study, PCSR is considered in relation to the employment of people with disabilities in the field of barista for the first time. Based on the study results, the formation of customers' behavioral intentions would be clearly explained in conjunction with PCSR and attitude toward using a brand. Furthermore, since the data from the hospitality sector have shown the reluctance in welcoming disabled people at a workplace [10], it would be meaningful to examine the differences in the effects of PCSR on attitude toward using a brand between non-disabled and disabled baristas. Therefore, our study has sought to address the following research questions: (1) What influence would PCSR have on attitude toward using a brand in the coffee industry? (2) How does attitude toward using a brand 
impact on behavioral intentions (i.e., intentions to use, word-of-mouth intentions, and willingness to pay more)? and (3) Does barista disability status play a moderating role in the link between PCSR and attitude toward using a brand?

\section{Literature Review}

\subsection{Corporate Social Responsibility (CSR) and Philanthropic CSR (PCSR)}

CSR is described as "a company's commitment to minimizing or eliminating any harmful effects and maximizing its long-run beneficial impact on society" [28]. CSR is identified by four categories of responsibilities which are economic, legal, ethical, and philanthropic [12]. Carrol [12] explained that economic and legal responsibilities are required of corporations, ethical responsibilities are what companies are expected to hold, and philanthropic responsibilities are what enterprises are desired to have. Furthermore, Carroll [12] asserted economic and legal responsibilities represent the traditional responsibilities of corporations, whereas ethical and philanthropic responsibilities reflect the modern responsibilities of the companies. Likewise, PCSR was regarded as the essence of CSR in modern times [12,13].

More recently, the types of CSR practices were classified into philanthropy, value chain, and ecosystem [14]. Rangan, Chase, and Karim [14] explicated that each of them plays an important role in addressing social and environmental problems, and a company should concentrate on types of programs depending on its ability, capacity, and core competencies. Philanthropy encompasses voluntary actions that corporates undertake as a response to society's expectation either in the form of financial support or in-kind donations of products and services to non-profit and community service organizations [14,29]. In other words, it involves all kind of charitable endeavors for the public. Examples include the funding for social or environmental programs, actively promoting goodwill or welfare, contributions to the arts, community, or education programs. For example, Goldman Sachs rolled out the "10,000 Women" initiative, which was a consolidation of its workforce diversity and "philanthropic efforts behind a big idea" to support female entrepreneurs in developing countries [30]. The company provided significant CSR resources to the program such as training for business and management skills, and successfully illustrated how their corporate philanthropy can service a social purpose that they care about. Starbucks' CSR campaign with the slogan "Are you in?" is another example; the company provided a free cup of coffee in exchange of hours of documented community service [31]. Lii and Lee [31] stressed how such campaigns provided a platform to induce consumers to do something meaningful for society and also helped reinvigorate the corporate image.

Meanwhile, value chain is centered on the improvement of operational effectiveness in increasing business opportunities or profitability while also providing social and environmental benefits $[14,32]$. That is, corporations seek to reengineer their entire value chain that includes sourcing, manufacturing, shipping, and delivery. Thus, innovative technology solutions and new manufacturing are often recognized in this category since they contribute to reducing both operating costs and environmental impact [33]. The last CSR domain is initiatives to transform the corporate business model to the ecosystem in order to create solutions to environmental or social challenges. These activities may not bring immediate returns to corporations but foster long-term returns and business opportunities. Hence, it requires the assurance of executive committees to focus on long- range business strategies rather than short-term financial gains. Comprehensive initiatives in the automobile industry are common examples that demonstrate its engagement in many aspects of renewable energy production and electric vehicle production to address global warming and climate change [34].

Numerous scholars in the existing studies have drawn attention to the missing link between CSR activities and consumer behavior by questioning whether consumers are aware of CSR initiatives [28,35-37]. Considering this matter, the present research is centered on philanthropy among aforementioned categorized CSR programs within the area of what consumers can easily evaluate through various communication channels $[19,38]$, and what are considered as the essence in today's world $[12,13,39]$. 
PCSR was defined as "corporate actions that are in response to society's expectation that businesses be a good corporate citizen" [13]. As previously explained, making donations for community improvements were often examples of activities of PCSR. Such monetary and non-monetary support was found in various areas such as academic and health programs. Furthermore, PCSR is not bound by directive aid made by companies but extended to the encouragement of philanthropic activities by associates and customers through various collaborations [40]. In other words, it includes inspiring and inducing philanthropic activities by participating the programs initiated by companies or partnered with a third-party. Airlines' fund-raising to support the welfare of children, namely UNICEF's Change for Good (CFG) program, by encouraging passengers' donation of spare foreign currency on flights can be one of many examples in the field of hospitality [41]. People with disabilities are regarded as the world's largest minority [3], and sufficient statistics showed that employing people with disabilities were largely overlooked [6-8]. With respect to this, involving disabled people in the labor market is a good deed reflecting PCSR as it promotes an inclusive culture and recognizes the diversity in the workplace. In this context, Starbucks Korea launched the program to embrace diversity by employing baristas with disabilities, and 409 baristas with disabilities, as of the end of 2019, work at the company's stores across the country [42]. Another example in the food service industry is McDonald's in Korea, which provided senior internship programs since 2012 in consideration of the ageing society [20].

\subsection{Effect of Philanthropic CSR (PCSR) on Attitude toward Using a Brand}

Attitude refers to a psychological tendency that is reflected by the evaluation of a particular entity with some degree of favor or disfavor [43]. Following this concept, attitude toward using a brand was defined as a consumer's internal evaluation of the brand [44]. It was further elaborated as an enduring state and was conceptualized as "a relatively enduring, unidimensional summary evaluation of the brand that presumably energizes behavior" [45]. Thus, consumer attitude toward using a brand is an important clue for corporations since a brand is what differentiated itself from the competition [46].

Many studies have demonstrated that consumers exhibit a positive attitude toward organizations engaged in CSR activities which create a more favorable image of a company or brand [11-15,18]. Especially, studies confirmed that PCSR generated consumers' positive feelings and resulted in the improvements in consumer attitude toward the company [19-23]. In other words, the diverse forms of PCSR programs play a prominent role in enhancing customer attitude [13]. Particularly, Rangan et al. [14] described the role of business in creating value for society and they asserted that corporate programs to fund social and environmental activities are of utmost importance to boost their brand reputation. In a similar vein, Mohr and Webb [23] examined the impact of CSR within the domain of environment and philanthropy on consumer responses, and their results indicated the significant positive effect of PCSR on evaluation of the company. That is to say, PCSR enhances corporate reputation, thus it plays an important role in enhancing customers' favorable attitude toward a brand [13]. Pino et al. [19] investigated the impact of company's philanthropic responsibilities on consumer attitude toward a specific food market. They analyzed the data collected from 260 Italians, and the results showed the positive influence in such relationship. More recently, Hwang, Cho, and Kim [20] conducted an empirical study using 546 responses subject to McDonald's PCSR practice and confirmed that PCSR fostered a favorable consumers' attitude toward using a brand. Conversely, some case studies argued that consumers are not much directly impacted by PCSR based on the aspect of its monetary donation to third-parties [18,47]. Therefore, it would be interesting to examine the case of Starbucks Korea's PCSR in engaging the employment of disabled people and the impact on consumers' attitude toward using a brand. In line with these findings and supporting background, the following hypothesis was developed: 
Hypothesis 1 (H1). Philanthropic corporate social responsibility exerts a positive influence on attitude toward using a brand.

\subsection{Effect of Attitude toward Using a Brand on Behavioral Intentions}

Behavioral intentions refer to the likelihood of individuals' engagement with a specific behavior [48] and various sub-dimensions of behavioral intentions were proposed in previous studies $[24,25,49]$. To be specific, the following three sub-dimensions were either individually or collectively suggested in the extant literature: Intentions to use, word-of-mouth intentions, and willingness to pay more. Intentions to use was explained similarly with the concept of the intentions to buy, purchase or visit and it can be described as the degree to which an individual plans to use specific goods and/or services [50]. Meanwhile, word-of-mouth intentions refer to the likelihood of informal person to person communications regarding particular products/service or a brand [51]. Willingness to pay more was described as the probability of consumer willingness to pay more to a particular product or service [52].

Many prior studies demonstrated the significant influence of attitude toward using a brand on behavioral intentions which encompass intentions to use, word-of-mouth intentions, and willingness to pay more. Phillips et al. [53] investigated US customers' intentions to try novel foods, and their analysis results revealed that attitude toward the novel foods increased the intentions to try new food. Similarly, Pino et al. [19] specifically illustrated how attitude toward genetically modified foods was related to intentions to buy. Spears and Singh [45] distinguished between attitude toward a brand and purchase intentions and articulated how they are closely related. Word-of-mouth intentions were also verified as an outcome of attitude toward using a brand [24,49,54]. Hwang, Lee, and Kim [24] conducted an empirical study based on 324 samples to predict customers' behavioral intentions in the drone-based food delivery context and confirmed the strong association between attitude toward using drone food delivery services and word-of-mouth intentions. Regarding the link between attitude toward using a brand and willingness to pay more, Schubert et al. [25] confirmed a significant association between attitude toward a company and willingness to pay more for the restaurants that proactively involved in green practices as part of CSR. Furthermore, they demonstrated over twenty percent of a total of 455 samples were willing to pay ten percent more for green restaurants. Hultman, Kazeminia, and Ghasemi [55] uncovered the significant relationship between attitude toward ecotourism and willingness to pay extra based on a survey collected from Swedish and Taiwanese tourists. Meanwhile, there are studies that tested sub-dimensions of behavioral intentions individually, and the results showed that the impact was neither the same way nor same level. For instance, Han et al. [49] adopted multi-dimensions of eco-friendly attitude and explored the influence of attitude toward green activities on intentions to visit, word-of-mouth intentions, and intentions to pay more in the green hotel context. Their results revealed that importance of being environmentally friendly was the most salient factor influencing intentions to visit and word-of-mouth intentions, whereas level of responsibility of business corporate had the greatest impact on intentions to pay more. The meaningful impact of attitude toward using a brand on behavioral intentions similarly exists in the area of PCSR. As an example, Lii and Lee [30] examined the effect of PCSR and confirmed the significant relationship between attitude built based on a company's PCSR activities and consumer behavior. Given the increased correspondence between attitude toward using a brand and behavioral intentions, the following hypotheses were proposed:

Hypothesis 2 (H2). Attitude toward using a brand exerts a positive influence on intentions to use.

Hypothesis 3 (H3). Attitude toward using a brand exerts a positive influence on word-of-mouth intentions.

Hypothesis 4 (H4). Attitude toward using a brand exerts a positive influence on willingness to pay more. 


\subsection{Moderating Role of Barista Disability Status}

The disabled are often perceived as being lazy, weak, or less committed, and thus they are required more assistance or supervisions, and more training [56-58]. These negative stereotypes or misconceptions explain the current employment rate for disabled people, which is far lower than that for non-disabled people [6,7]. Nonetheless, studies have found the work performance of people with disabilities is rather positive. That is, low turnover, high commitment, and productivity were generally described in the evaluation of disabled employees' performance [59,60]. Likewise, Kalargyrou [61] used qualitative methods by collecting opinions from two representing firms in disability inclusion, and asserted hiring disabled people brings competitive advantages due to the fact that employees with a disability perform better in terms of attendance and employee engagement. Lindsay et al. [62] reviewed articles involving disabled people at the workplace published from 1997 to 2017, and their findings showed various benefits of hiring people with disabilities such as profitability based on reliability and punctuality, competitive advantage related to customer loyalty, and inclusive work culture.

A few attempts were made to investigate the different effects depending on disability status in various settings. For example, Strauser, Lustig, and Uruk [26] examined the moderating role of disability status in the link between trauma symptomatology and variables related to career. Kuo and Kalargyrou [27] tested whether the consumers' responses differ based on disability status of service staff at the casual dining restaurant, and their results suggested that restaurants targeting family/friends gatherings would gain advantage by hiring people with a disability. On the other hand, various moderating variables (e.g., collectivism, ecocentric tendencies, and masculinity) were verified in the association between CSR and customers' various responses [63,64]. Kang and Namkung [18] identified the moderating role of ethical consumerism in the relationship between CSR and brand equity. Concretely, the impact of economic CSR on brand equity was greater for consumers with a high degree of ethical consumerism. Yet, to date, no completed study has conducted how barista disability status affects the relationship between PCSR and attitude toward using a brand. Numerous studies focused on the employment of people with disabilities and they recognized the prejudice against disabled people and misunderstandings about their work performance as well as customers' evaluations [56-62]. Likewise, a consumer's attitude that is more favorable exhibits toward corporations that hire people with disabilities according to a national survey [65]. Referring these findings and discussions above, it is reasonable that the moderating effect of disability status exists in the link between PCSR and attitude toward using a brand. Thus, the following hypothesis was anticipated:

Hypothesis 5 (H5). Barista disability status moderates the relationship between philanthropic corporate social responsibility and attitude toward using a brand.

On the basis of this background, Figure 1 illustrates the conceptual model which includes the hypothesized relationships among study variables and moderating role of barista disability status. More specifically, the current research borrowed a stimulus-organism-behavior (SOB) paradigm that is similar to the study conducted by Lii and Lee [30], and it was mapped out for the investigation of the associations among PCSR, attitude toward using a brand, and behavioral intentions. In addition, this study was designed to identify the moderating effect of barista disability status in the relationship between PCSR and attitude toward using a brand in a case study of Starbucks that is similar to the study conducted by Kang and Namkung [18]. 


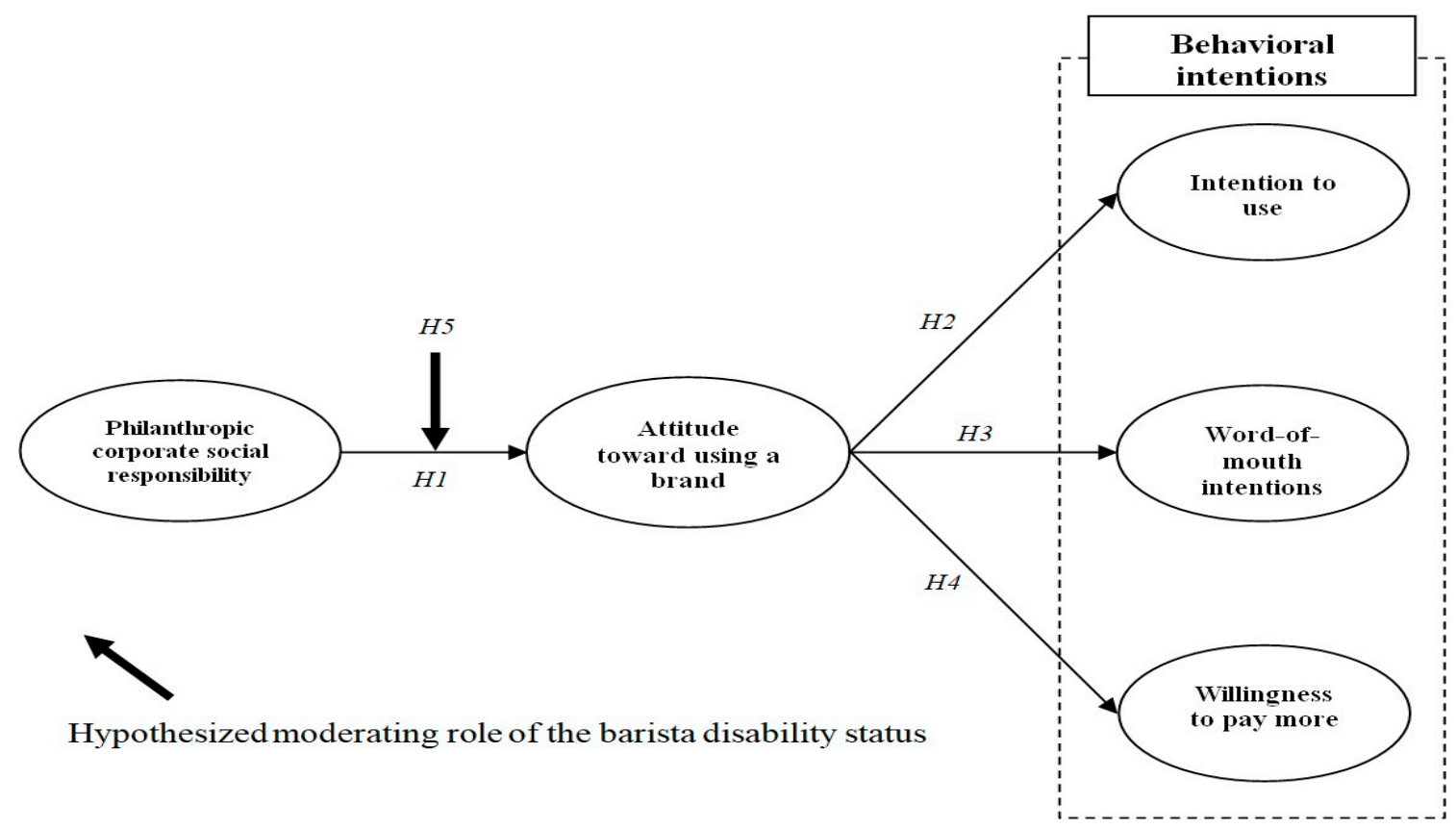

Figure 1. Proposed conceptual model.

\section{Method}

\subsection{Measures}

This study employed multiple-item scales in order to measure five constructs including PCSR, attitude, intentions to use, word-of-mouth intentions, and willingness to pay more. First, PCSR was measured with four items that were adapted from Carroll [11] and Hwang et al. [20]. Second, attitude was measured based on three items that were used by Hwang and Hyun [66] and Mitchell and Olson [44]. Third, intentions to use were measured employing three items that were borrowed from Hwang and Lee [67] and Zeithaml, Berry, and Parasuraman [68]. Fourth, word-of-mouth intentions were measured with three items that were borrowed from Hwang and Choi [69] and Hennig-Thurau, Gwinner, and Gremler [70]. Fifth, willingness to pay more was measured with three items used by Hwang et al. [24] and Hwang and Kim [71]. All items were measured with a five-point Likert's scale ( 1 = strongly disagree and $5=$ strongly agree). To check the reliability of the measurement items, a pre-test was performed with 30 actual coffee shop customers using an offline survey. The results showed a high level of reliability as Cronbach's $\alpha$ values were greater than 0.70 [72].

\subsection{Data Collection}

In order to test the moderating role of barista disability status, the questionnaire was distributed to customers who have experienced one of two types of Starbucks coffee shops within the last three months in Korea using an on-site survey. In the case of Type 1 Starbucks, disabled baristas provide services, while regarding Type 2 Starbucks, non-disabled baristas provide services. Two surveys were performed in order to collect data from customers who have drunk coffee at Type 1 and Type 2 coffee shops separately. All interviewers received intensive training to understand the objective of the current study, and then they received additional education about data collection techniques. As mentioned earlier, disabled baristas work at Starbucks in Korea. As these baristas work wearing a yellow badge, customers can easily see that they are disabled people. The interviewers waited in front of the coffee shop and conducted a survey of customers coming out of the coffee shop. In addition, before starting the survey, the interviewers gave the respondents a full explanation of the purpose of the survey.

The questionnaire was distributed to customers who have experienced one of the following two types of Starbucks coffee shops within the last three months in Korea using an on-site survey: 
Type 1 Starbucks: Disabled baristas provide services.

Type 2 Starbucks: Non-disabled baristas provide services.

A total of 577 responses were collected including 286 customers who have used the Type 1 coffee shop and 291 who have used the Type 2 coffee shop, respectively. After Mahalanobis distance check, five outliers were excluded. Consequently, 572 usable responses were employed for further analysis.

\section{Data Analysis}

\subsection{Demographic Characteristics of the Respondents}

Table 1 provides the demographic characteristics of the respondents. Among the participants, a total of 237 respondents were male customers $(41.4 \%)$ and 335 respondents were female customers (58.6\%). Regarding monthly household income, approximately $41.2 \%$ of the participants indicated that their household income ranged from US $\$ 1001$ to US $\$ 2000$. About $82.1 \%$ of the survey participants were single, and their mean age was 28.42 years old. Lastly, $47.9 \%$ of the participants indicated that they held a bachelor's degree.

Table 1. Profile of survey respondents $(n=572)$.

\begin{tabular}{|c|c|c|}
\hline Variable & $n$ & Percentage \\
\hline \multicolumn{3}{|l|}{ Gender } \\
\hline Male & 237 & 41.4 \\
\hline Female & 335 & 58.6 \\
\hline \multicolumn{3}{|l|}{ Monthly household income } \\
\hline US $\$ 4001$ and over & 16 & 2.7 \\
\hline US \$3001-US \$4000 & 42 & 7.3 \\
\hline US \$2001-US \$3000 & 135 & 23.6 \\
\hline US \$1001-US \$2000 & 236 & 41.2 \\
\hline Under US $\$ 1000$ & 143 & 25.0 \\
\hline \multicolumn{3}{|l|}{ Marital status } \\
\hline Single & 470 & 82.1 \\
\hline Married & 102 & 17.9 \\
\hline \multicolumn{3}{|l|}{ Education level } \\
\hline Less than High school diploma & 17 & 2.9 \\
\hline Associate's degree & 161 & 28.1 \\
\hline Bachelor's degree & 274 & 47.9 \\
\hline Graduate degree & 120 & 21.1 \\
\hline Mean age $=28.42$ years old & & \\
\hline
\end{tabular}

\subsection{Confirmatory Factor Analysis}

The measurement structure of the proposed conceptual model was assessed using a confirmatory factor analysis (CFA). The CFA model showed a satisfactory fit to the data $\left(\chi^{2}=313.738, \mathrm{df}=94\right.$, $\chi^{2} / \mathrm{df}=3.338, p<0.001, \mathrm{NFI}=0.946, \mathrm{CFI}=0.961, \mathrm{TLI}=0.951$, and RMSEA $=0.063$ ). All factor loadings were equal to or greater than 0.783 and were significantly loaded to their related latent construct $(p<0.001)$. The specific variables employed in the current study and their standardized factor loadings are summarized in Table 2. 
Table 2. Confirmatory factor analysis: items and loadings.

\begin{tabular}{|c|c|}
\hline Construct and Scale Items & Standardized Loading ${ }^{a}$ \\
\hline \multicolumn{2}{|l|}{ Philanthropic corporate social responsibility } \\
\hline This coffee shop brand is committed to build a better community. & 0.812 \\
\hline This coffee shop brand provides a variety of donations. & 0.848 \\
\hline This coffee shop brand develops a campaign for helping the needy. & 0.839 \\
\hline This coffee shop brand participates in a variety of volunteer activities. & 0.795 \\
\hline \multicolumn{2}{|l|}{ Attitude toward using a brand } \\
\hline My attitude toward using this coffee shop brand was good. & 0.857 \\
\hline My attitude toward using this coffee shop brand was favorable. & 0.783 \\
\hline My attitude toward using this coffee shop brand was positive. & 0.823 \\
\hline \multicolumn{2}{|l|}{ Intention to use } \\
\hline I would keep visiting this coffee shop brand in the future. & 0.808 \\
\hline I am more likely to visit this coffee shop brand next time. & 0.838 \\
\hline I would revisit this coffee shop brand in the future. & 0.809 \\
\hline \multicolumn{2}{|l|}{ Word-of-mouth intentions } \\
\hline I am likely to say positive things about this coffee shop brand to others. & 0.801 \\
\hline I am likely to recommend this coffee shop brand to others. & 0.880 \\
\hline I am likely to encourage others to use this coffee shop brand. & 0.806 \\
\hline \multicolumn{2}{|l|}{ Willingness to pay more } \\
\hline I am likely to pay more for this coffee shop brand. & 0.854 \\
\hline It is acceptable to pay more for this coffee shop brand. & 0.866 \\
\hline I am likely to spend extra in order to use this coffee shop brand. & 0.885 \\
\hline
\end{tabular}

As presented in Table 3, the composite reliability values fell within the range between 0.902 and 0.872 , which exceeded the recommended level of 0.600 [73]. In addition, the values of average variance-extracted (AVE) estimates for the current study constructs ranged from 0.670 to 0.754 , which were higher than the suggested cutoff of 0.500 [74]. This means that there is a high level of convergent validity. Lastly, the constructs met Fornell and Larcker's [72] criterion, as the AVE values for each variable were greater than all of the squared correlations $\left(R^{2}\right)$ between all possible pairs of constructs, suggesting the satisfactory discriminant validity.

Table 3. Descriptive statistics and associated measures.

\begin{tabular}{|c|c|c|c|c|c|c|c|}
\hline & Mean (SD) & AVE & (1) & (2) & (3) & (4) & (5) \\
\hline $\begin{array}{l}\text { (1) Philanthropic corporate } \\
\text { social responsibility }\end{array}$ & $4.07(0.70)$ & 0.694 & $0.872^{\mathrm{a}}$ & $0.462^{b}$ & 0.312 & 0.507 & 0.527 \\
\hline (2) Attitude & $4.02(0.75)$ & 0.675 & $0.213^{\mathrm{c}}$ & 0.862 & 0.416 & 0.548 & 0.261 \\
\hline (3) Intention to use & $3.91(0.68)$ & 0.670 & 0.097 & 0.173 & 0.859 & 0.465 & 0.307 \\
\hline (4) Word-of-mouth intentions & $4.02(0.69)$ & 0.689 & 0.257 & 0.300 & 0.216 & 0.869 & 0.409 \\
\hline (5) Willingness to pay more & $3.61(0.84)$ & 0.754 & 0.278 & 0.068 & 0.094 & 0.167 & 0.902 \\
\hline
\end{tabular}

Notes 1: $\mathrm{SD}=$ standard deviation and AVE $=$ average variance extracted. Notes 2: ${ }^{a}$ Composite reliabilities are along the diagonal; ${ }^{\mathrm{b}}$ Correlations are above the diagonal; ${ }^{\mathrm{c}}$ Squared correlations are below the diagonal. 


\subsection{Structural Equation Modeling}

To empirically test the hypothesized relationships, a structural equation modeling (SEM) was conducted. The overall evaluation of the model fit showed a satisfactory fit of the model to the data $\left(\chi^{2}=378.659, \mathrm{df}=100, \chi^{2} / \mathrm{df}=3.786, p<0.001, \mathrm{NFI}=911, \mathrm{CFI}=0.927, \mathrm{TLI}=0.912\right.$, and RMSEA $\left.=0.085\right)$. All four proposed hypotheses were statistically supported at $p<0.05$. More specifically, PCSR has a positive influence on attitude $(\beta=0.520, p<0.05)$. Hence, Hypothesis 1 was supported. In addition, the SEM results showed that attitude positively affected intentions to use $(\beta=0.459, p<0.05)$, word-of-mouth intentions ( $\beta=0.602, p<0.05)$, and willingness to pay more $(\beta=0.341, p<0.05)$, supporting Hypotheses 2, 3, and 4. Results of the SEM are summarized in Table 4.

Table 4. Standardized parameter estimates for structural model.

\begin{tabular}{ccccc}
\hline & & Coefficients & $t$-Value & Hypothesis \\
\hline $\begin{array}{c}\text { H1 Philanthropic corporate } \\
\text { social responsibility }\end{array}$ & Attitude & 0.520 & $11.220^{*}$ & Supported \\
H2 Attitude & Intention to use & 0.459 & $9.464^{*}$ & Supported \\
H3 Attitude & Word-of-mouth intentions & 0.602 & $12.145^{*}$ & Supported \\
H4 Attitude & Willingness to pay more & 0.341 & $7.141^{*}$ & Supported \\
\hline
\end{tabular}

Goodness-of-fit statistics: $\chi^{2}=378.659, \mathrm{df}=100, \chi^{2} / \mathrm{df}=3.786, p<0.001, \mathrm{NFI}=911, \mathrm{CFI}=0.927$, TLI $=0.912$, and RMSEA $=0.085$. Notes $1:{ }^{*} p<0.05$. Notes 2: NFI $=$ Normed Fit Index, CFI $=$ Comparative Fit Index, TLI $=$ Tucker-Lewis Index, and RMSEA $=$ Root Mean Square Error of Approximation.

\subsection{Moderating Role of the Barista Disability Status}

In order to test the moderating role of the barista disability status, the current study employed multiple-group analyses by comparing the chi-square difference between the unconstrained and constrained models based on the difference in degrees of freedom [75]. The results of the multiple-group analyses showed that the barista disability status moderated the relationship between PCSR and attitude $\left(\Delta \chi^{2}=8.011>\chi^{2}=0.5(1)=3.84, \mathrm{df}=1\right)$, which supported Hypothesis 5. More specifically, the path coefficients for the disabled barista group $(\beta=0.715, p<0.05)$ were found to be higher than for the non-disabled barista group $(\beta=0.332, p<0.05)$. Figure 2 shows the results of the multiple-group analyses.

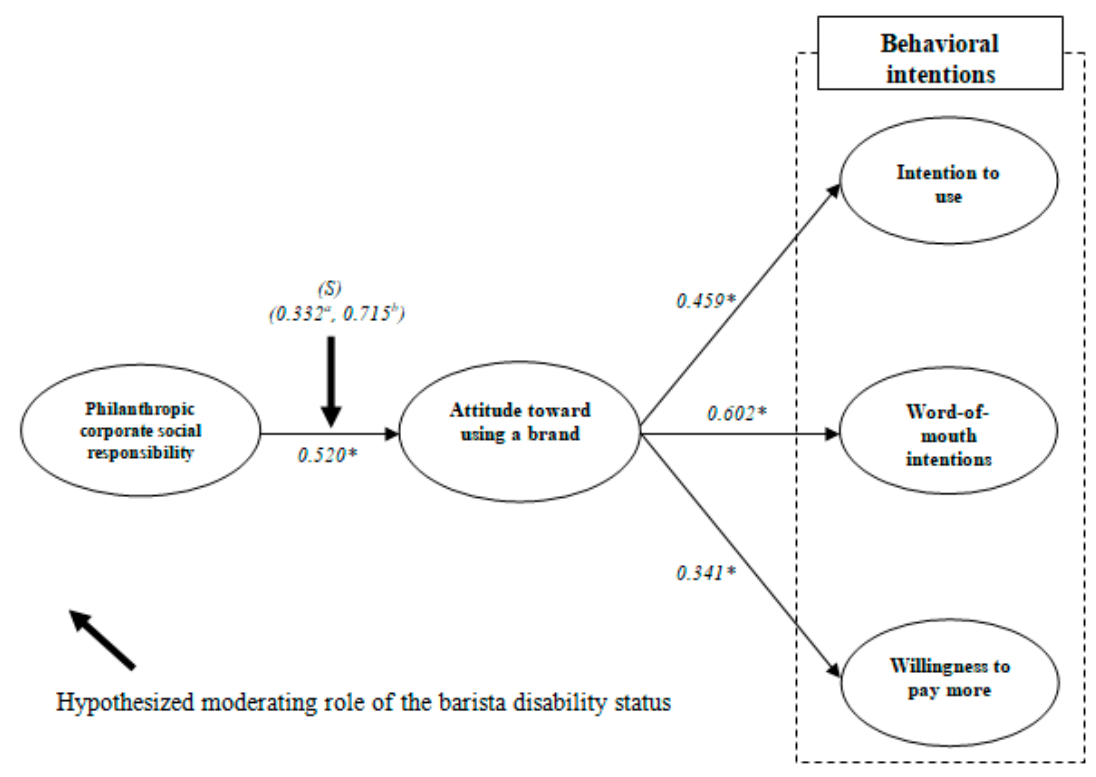

Notes 1: ${ }^{*} p<0.05$. Notes 2: $\mathrm{S}=$ Significant. Notes 3: a. Path coefficient for non-disabled barista,

b. Path coefficient for disabled barista coefficient for disabled barista

Figure 2. Standardized theoretical path coefficients. 


\section{Discussion and Implications}

Several issues have newly emerged in modern society including increased amount of senior citizens and people with disabilities due to the accelerated ageing phenomenon. As such, there is greater demand on PCSR initiatives on these areas [20,23]. Diverse activities under the theme of PCSR were introduced, and studies provided evidence of the considerable influence of those PCSR programs on customers' responses in various settings $[19,20,23,36]$. Nonetheless, there are limited findings that explain how consumers respond to the growing employment of disabled people as part of PCSR activities. On the basis of this background, the present research attempted to conduct an empirical study to validate such relationship in a coffee shop sector. Starbucks Coffee Company has launched a wide array of CSR activities [16-18], and more notably, Starbucks Korea stands out as looking after the weaker members in the labor market. To be specific, Starbucks Korea proactively recruits disabled baristas and sets a great example of PCSR in the coffee industry. Thus, our study has taken the case of Starbucks Korea to test the associations among PCSR, attitude toward using a brand, and behavioral intentions. The results of analysis successfully verified the significance in proposed paths, and our study enriched the extant literature by providing empirical evidence in the coffee retailing context.

Second, many scholars demonstrated the various benefits that corporations may gain through CSR initiatives, and a favorable attitude, brand preferences, and good reputation were constantly mentioned as outcomes of PCSR $[20,23]$. In other words, PCSR is a vital clue for the improvement of competitive advantage. Our study is in line with the extant literature based on the analysis results which statistically supported the positive influence of PCSR on attitude toward using a brand (Hypothesis 1). Therefore, entrepreneurs in the coffee industry should initiate more and steady PCSR practices, which also have a profound effect on customers' positive attitude toward a brand, and therefore, such initiatives will generate the synergetic effect of various pillars supporting the brand and the entire concept. Likewise, practitioners in the coffee shops continuously look into contemporary issues such as increased people with disabilities in a local community and contributing their share to the social well-being. Moreover, studies pertaining to CSR communications suggested that CSR initiatives should not be communicated directly to consumers in order to reduce consumer skepticism, and stated other key elements such as message sources to be considered in communicating CSR practices [76,77]. That is, a firm's intensive advertisements of their own CSR activities create negative images of the company. Instead, scholars provided evidence that publicity generated more positive evaluations and recommended the third-party or non-corporate sources and interactive media to communicate their social initiatives [76-78]. Thus, the communication strategy is of critical importance and devising PCSR activities should involve the detail-oriented communication plans. Furthermore, nowadays, companies initiating CSR activities are regarded as obligatory and as a matter of course, to some extent $[18,20]$. Hence, companies should wisely communicate selected PCSR activities which are more relevant to their industry and contemporary issues using selected channels. For example, coffee service providers may encourage consumer- generated contents to indirectly showcase their PCSR programs on online communities.

Third, the present study successfully tested the association between attitude toward using a brand and each sub-dimension of behavioral intentions. The analysis results confirmed the significant influence of attitude toward using a brand on intentions to use (Hypothesis 2), word-of-mouth intentions (Hypothesis 3), and willingness to pay more (Hypothesis 4). These are coherent with prior studies $[19,24,25]$, suggesting attitude toward using a brand is a crucial indicator of these underlying dimensions of consumers' behavioral intentions. Therefore, individuals' favorable attitude built by companies' proactive PCSR activities could induce customers to choose a particular company over other suppliers. Especially, along with the studies conducted in the area of CSR communication strategies, the power of word-of-mouth was further stressed as it is a non-commercial communication channel which is generally considered as fair and unbiased [79,80]. Thus, transmitting positive word-of-mouth would be an essential tool for firms' PCSR practices, and industry practitioners should encourage more word-of-mouth. For instance, utilizing meaningful activities related to PCSR on social network sites or offline campaigns for consumers to participate in PCSR initiatives would allow consumers to create 
some space for the stories. For example, adopting current practices in other industries, consumers could be given a choice of PCSR activities when they purchase products at a coffee shop. A choice of PCSR activities can range from a small amount of cash donation or buy one and give one. Alternatively, companies may run a contest to collect and select the specific type of PCSR activities which consumers feel important to carry on and execute them together. Having consumers to personally participate in PCSR activities would be helpful for them to spread the word not only about their good deeds but also how they are involved in these initiatives together with companies.

Fourth, the moderating effect of barista disability status was uncovered in the relationship between PCSR and attitude toward using a brand for the first time. In this regard, the present study is original and contains meaningful implications. To be specific, the magnitude of the link between PCSR and attitude toward using a brand ( $\beta$ disabled barista group $=0.715, p<0.05 ; \beta$ non-disabled barista group $=0.332, p<0.05$ ) was greater in the group of customers who were serviced by baristas with disabilities. That is, the results indicated that PCSR activities improved a stronger degree of consumers' favorable attitude toward using a brand from the synergy created by employing disabled baristas in a coffee shop. Hence, practitioners in the coffee industry should recognize how employing disabled baristas would contribute both in participating PCSR and consumer responses, and proactively hire disabled baristas. On the other hand, policy makers around the world are committed to the endeavor to increase employment-population ratios through regulations or quota systems [4,5]. In spite of that, employment rates are relatively lower in hospitality than other industries [8-10]. Thus, empirical evidence derived from our study can be used to arouse the professionals in the coffee industry to the benefits of employing disabled baristas. Furthermore, Rangan et al. [14] suggested that types of CSR programs should be wisely selected depending on corporations' ability, capacity, and core competencies. For a short-term tactic to ramp up the current status to the average, it is needed to recognize that the level of possible deployment of disabled employees varies by industry, and accordingly, a differential set of realistic goals for different fields would be required. Therefore, flexible approaches improving in disability inclusion are necessary. For example, a differentiated quota system or more incentives might be considered for companies with heavy positions that come face-to-face with consumers. Such policies would trigger stronger motivation for companies to hire disabled people. In addition to this, the official systems running by government or non-profit organizations to recognize and reward these service providers are recommended. Referring to the effective CSR communication strategies previously mentioned, companies could gain benefits by such systems initiating the indirect marketing effect on their efforts in hiring disabled baristas. Likewise, associations and governmental bureaus should place these service providers as great examples of PCSR and promote them from their end. At the same time, companies in the coffee retailing field may make their efforts in highlighting the presence of disabled employees. As an example case of Starbucks Korea, disabled baristas wearing a yellow badge, and having customers to easily notice disabled baristas in a coffee shop would be effective. In other words, the deployment of disabled baristas will contribute better in marketing communications instead of putting in an enormous amount of effort and resources into placing advertisements or publicity. Taking it a step further, revamping venues as disabled-friendly coffee shops is suggested. For instance, apart from hiring disabled baristas, a branch could be fully equipped for convenience of the disabled customers, or the management could consider creating a zone for disabled customers such as a place with more spaces for wheelchairs. Such special zones can be designed not only for the disabled but also for customers who require more attention such as pregnant women and senior citizens. This would create a substantial marketing effect that will positively influence a company's success through customers' favorable attitude toward using a brand.

\section{Limitations and Future Research}

The current study has a few limitations that outline the directions for future research. Although the study took the well-known coffee retailing company that initiated various CSR activities, our empirical analysis results are based on a sample from one particular coffee chain company. In this respect, it is 
somewhat insufficient to the generalizability of the results across other settings in the service industry. Additionally, cultural aspects were not considered in the present research, even though the existing findings denoted the different responses to CSR initiatives across different nationalities [33]. Thus, it is difficult to apply the results of this study globally and, accordingly, the sample collection for future studies is needed in the light of cultural background. Future studies are suggested to design and provide empirical evidences in other settings of service encounter, so it would contribute to encourage various corporations in the hospitality industry to increase their employment rates for people with disabilities. Third, this study failed to consider the different types of disabilities that might influence consumers' responses in the different ways. Thus, it is better to categorize employees with disabilities depending on the types of disabilities and consider this in designing a future study. In addition, situational factors were excluded in developing our theoretical framework. Based on the studies that examined external factors such as dining occasion in consumers' responses [27], testing additional moderating variables is recommended. Lastly, the questionnaire did not fully reflect the hypotheses. For example, in the case of willingness to pay more, future studies need to supplement this issue because the exact amount of money respondents could pay was not actually measured.

\section{Conclusions}

Disability rates are increasing due to the ageing population and increases in chronic health conditions [1,2], and this research brought attention to the PCSR activities in this specific area. Starbucks Korea has set an example for PCSR by proactively hiring disabled baristas. Accordingly, the present study took Starbucks Korea as a case in point and successfully examined the impact of PCSR on the formation of customers' behavioral intentions. That is, the current study provided empirical evidence that PCSR activities led to favorable customer attitude toward using a brand, which, in turn, induced stronger behavioral intentions in a coffee retailing sector. In addition, the present study identified the moderating role of barista disability status which has not been investigated as of yet. The findings of this study provided the insightful implications for theory and practice that include the encouragement of hiring people with disabilities in the coffee shops. Therefore, the current research would be an invaluable resource in addressing particular needs of a contemporary issue in the hospitality sector.

Author Contributions: Conceptualization, J.H.; methodology, J.H.; validation, J.H.; formal analysis, J.H.; investigation, J.H.; data curation, S.L.; writing—original draft preparation, J.H. and J.J.K.; writing—review and editing, J.H. and J.J.K.; supervision, J.H.; project administration, J.H.; All authors have read and agreed to the published version of the manuscript.

Funding: This research received no external funding.

Conflicts of Interest: The authors declare no conflict of interest.

\section{References}

1. World Health Organization. Disability and Health Website. Available online: http://www.who.int/newsroom/fact-sheets/detail/disability-and-health (accessed on 16 February 2020).

2. Iriarte, E.G.; McConkey, R.; Gilligan, R. (Eds.) Disability and Human Rights: Global Perspectives; Palgrave Macmillan: London, UK, 2015.

3. Khan, N.; Korac-Kakabadse, N.; Skouloudis, A.; Dimopoulos, A. Diversity in the workplace: An overview of disability employment disclosures among UK firms. Corp. Soc. Responsib. Environ. Manag. 2019, 26, 170-185. [CrossRef]

4. Parliament. People with Disabilities in Employment. Available online: https://researchbriefings.parliament. uk/ResearchBriefing/Summary/CBP-7540 (accessed on 16 February 2020).

5. The Korea Herald. Opening up Workplaces to People with Disabilities. Available online: http://www. koreaherald.com/view.php?ud=20190421000063\&ACE_SEARCH=1 (accessed on 16 February 2020).

6. U.S. Department of Labor Bureau of Labor Statistics. Available online: https://www.bls.gov/news.release/ pdf/disabl.pdf (accessed on 16 February 2020). 
7. Office for National Statistics. Disability and Employment, UK: 2019. Available online: https://www.ons.gov.uk/ peoplepopulationandcommunity/healthandsocialcare/disability/bulletins/disabilityandemploymentuk/2019 (accessed on 16 February 2020).

8. Donnelly, K.; Joseph, J. Disability Employment in the Hospitality Industry: Human Resources Considerations; Cornell HR Review: Ithaca, NY, USA, 2012; Available online: http://digitalcommons.ilr.cornell.edu/chrr/27 (accessed on 16 February 2020).

9. Hankyoreh. Starbucks Taking Lead in Hiring Disabled Workers as Baristas. Available online: http://english. hani.co.kr/arti/english_edition/e_business/780512.html (accessed on 16 February 2020).

10. Islam, R.; Patwary, A.K. Factors influencing to the policy and strategies used to disabled employment in hospitality industry. Adv. Environ. Biol. 2013, 7, 2598-2605.

11. Carroll, A.B. A three-dimensional conceptual model of corporate performance. Acad. Manag. Rev. 1979, 4, 497-505. [CrossRef]

12. Carroll, A.B. The pyramid of corporate social responsibility: Toward the moral management of organizational stakeholders. Bus. Horiz. 1991, 34, 39-48. [CrossRef]

13. Carroll, A.B.; Shabana, K.M. The business case for corporate social responsibility: A review of concepts, research and practice. Int. J. Manag. Rev. 2010, 12, 85-105. [CrossRef]

14. Rangan, K.; Chase, L.A.; Karim, S. Why Every Company Needs a CSR Strategy and How to Build It; Working Paper No. 12-088; Harvard Business School: Boston, MA, USA, 2012; pp. 1-31.

15. Kotler, P.; Lee, N. Corporate Social Responsibility: Doing the Most Good for your Company and your Cause; John Wiley \& Sons: Hoboken, NJ, USA, 2008.

16. Botero, M.E.; Díaz, A.M.A.; Cadavid, C.M.; Muhss, M. CSR practices in the coffee industry: A preliminary review of Kraft Foods, Nestlé and Starbucks. Rev. Neg. Int. 2011, 4, 30-44.

17. Niemuth, S.; Hamann, L.; Luschnat, K.; Smolarz, P.; Golombek, S. CSR in the coffee industry: Sustainability issues at Nestlé-Nespresso and Starbucks. J. Eur. Manag. Public Aff. Stud. 2014, 2, 31-36.

18. Kang, J.W.; Namkung, Y. The effect of corporate social responsibility on brand equity and the moderating role of ethical consumerism: The case of Starbucks. J. Hosp. Tour. Res. 2018, 42, 1130-1151. [CrossRef]

19. Pino, G.; Amatulli, C.; De Angelis, M.; Peluso, A.M. The influence of corporate social responsibility on consumers' attitudes and intentions toward genetically modified foods: Evidence from Italy. J. Clean. Prod. 2016, 112, 2861-2869. [CrossRef]

20. Hwang, J.; Cho, S.; Kim, W. Philanthropic corporate social responsibility, consumer attitudes, brand preference, and customer citizenship behavior: Older adult employment as a moderator. Soc. Behav. Personal. Int. J. 2019, 47, e8111. [CrossRef]

21. Brown, T.J.; Dacin, P.A. The company and the product: Corporate associations and consumer product responses. J. Mark. 1997, 61, 68-84. [CrossRef]

22. Sen, S.; Bhattacharya, C.B. Does doing good always lead to doing better? Consumer reactions to corporate social responsibility. J. Mark. Res. 2001, 38, 225-243. [CrossRef]

23. Mohr, L.A.; Webb, D.J. The effects of corporate social responsibility and price on consumer responses. J. Consum. Aff. 2005, 39, 121-147. [CrossRef]

24. Hwang, J.; Lee, J.S.; Kim, H. Perceived innovativeness of drone food delivery services and its impacts on attitude and behavioral intentions: The moderating role of gender and age. Int. J. Hosp. Manag. 2019, 81, 94-103. [CrossRef]

25. Schubert, F.; Kandampully, J.; Solnet, D.; Kralj, A. Exploring consumer perceptions of green restaurants in the US. Tour. Hosp. Res. 2010, 10, 286-300. [CrossRef]

26. Strauser, D.R.; Lustig, D.C.; Çiftçi Uruk, A. Examining the moderating effect of disability status on the relationship between trauma symptomatology and select career variables. Rehabil. Couns. Bull. 2006, 49, 90-101. [CrossRef]

27. Kuo, P.J.; Kalargyrou, V. Consumers' perspectives on service staff with disabilities in the hospitality industry. Int. J. Contemp. Hosp. Manag. 2014, 26, 164-182. [CrossRef]

28. Mohr, L.A.; Webb, D.J.; Harris, K.E. Do consumers expect companies to be socially responsible? The impact of corporate social responsibility on buying behavior. J. Consum. Aff. 2001, 35, 45-72. [CrossRef]

29. Han, H.; Yu, J.; Kim, W. Environmental corporate social responsibility and the strategy to boost the airline's image and customer loyalty intentions. J. Travel Tour. Mark. 2019, 36, 371-383. [CrossRef] 
30. Marquis, C.; Rangan, V.K.; Ross, C. Goldman Sachs: The 10,000 Women Initiative; HBS Case No. 509-042; Harvard Business Publishing: Boston, MA, USA, 2009.

31. Lii, Y.S.; Lee, M. Doing right leads to doing well: When the type of CSR and reputation interact to affect consumer evaluations of the firm. J. Bus. Ethics 2012, 105, 69-81. [CrossRef]

32. Han, H.; Chua, B.L.; Ariza-Montes, A.; Untaru, E.N. Effect of environmental corporate social responsibility on green attitude and norm activation process for sustainable consumption: Airline versus restaurant. Corp. Soc. Responsib. Environ. Manag. 2020, 27, 1851-1864. [CrossRef]

33. Nidumolu, R.; Prahalad, C.K.; Rangaswami, M.R. Why sustainability is now the key driver of innovation. Harv. Bus. Rev. 2009, 87, 56-64.

34. General Electric News Center. GE Announces National Electrical Vehicle Experience Tour to Engage Key Stakeholders on EV Deployment Strategies. Available online: https://www.businesswire.com/news/home/ 20110303006224/en/GE-Announces-National-Electric-Vehicle-Experience-Tour (accessed on 20 February 2020).

35. Maignan, I. Consumers' perceptions of corporate social responsibilities: A cross-cultural comparison. J. Bus. Ethics 2001, 30, 57-72. [CrossRef]

36. Pomering, A.; Dolnicar, S. Assessing the prerequisite of successful CSR implementation: Are consumers aware of CSR initiatives? J. Bus. Ethics 2009, 85, 285-301. [CrossRef]

37. Han, H.; Al-Ansi, A.; Chi, X.; Baek, H.; Lee, K.S. Impact of environmental CSR, service quality, emotional attachment, and price perception on word-of-mouth for full-service airlines. Sustainability 2020, 12, 3974. [CrossRef]

38. Han, H.; Yu, J.; Lee, K.S.; Baek, H. Impact of corporate social responsibilities on customer responses and brand choices. J. Travel Tour. Mark. 2020, 37, 302-316. [CrossRef]

39. Han, H.; Chi, X.; Kim, C.S.; Ryu, H.B. Activators of Airline Customers' Sense of Moral Obligation to Engage in Pro-Social Behaviors: Impact of CSR in the Korean Marketplace. Sustainability 2020, 12, 4334. [CrossRef]

40. Chen, J.C.; Patten, D.M.; Roberts, R. Corporate charitable contributions: A corporate social performance or legitimacy strategy? J. Bus. Ethics 2008, 82, 131-144. [CrossRef]

41. Kim, Y.; Yun, S.; Lee, J. Can companies induce sustainable consumption? The impact of knowledge and social embeddedness on airline sustainability programs in the US. Sustainability 2014, 6, 3338-3356. [CrossRef]

42. Yonhap News. Starbucks, the Open Recruitment of Baristas with Disabilities in Quarter One. Available online: https://www.yna.co.kr/view/AKR20200113040200030?input=1195m (accessed on 20 February 2020).

43. Eagly, A.H.; Chaiken, S. The Psychology of Attitudes; Harcourt Brace Jovanovich College Publishers: San Diego, CA, USA, 1993.

44. Mitchell, A.A.; Olson, J.C. Are product attribute beliefs the only mediator of advertising effects on brand attitude? J. Mark. Res. 1981, 18, 318-332. [CrossRef]

45. Spears, N.; Singh, S.N. Measuring attitude toward the brand and purchase intentions. J. Curr. Issues Res. Advert. 2004, 26, 53-66. [CrossRef]

46. Taylor, S.A.; Celuch, K.; Goodwin, S. The importance of brand equity to customer loyalty. J. Prod. Brand Manag. 2004, 13, 217-227. [CrossRef]

47. Choo, S.W.; Kim, H.B. The effect on the corporate society responsibility to corporate image and loyalty in the food-service franchise: Focus on the university student of hotel and food-service dept. J. Tour. Leis. Res. 2012, 24, 525-547.

48. Oliver, R.L. Satisfaction: A Behavioral Perspective on the Consumer; Irwin-McGraw-Hill: New York, NY, USA, 1997.

49. Han, H.; Hsu, L.T.J.; Lee, J.S.; Sheu, C. Are lodging customers ready to go green? An examination of attitudes, demographics, and eco-friendly intentions. Int. J. Hosp. Manag. 2011, 30, 345-355. [CrossRef]

50. Warshaw, P.R.; Davis, F.D. Disentangling behavioral intention and behavioral expectation. J. Exp. Soc. Psychol. 1985, 21, 213-228. [CrossRef]

51. Westbrook, R.A. Product/consumption-based affective responses and postpurchase processes. J. Mark. Res. 1987, 24, 258-270. [CrossRef]

52. Dodds, W.B.; Monroe, K.B.; Grewal, D. Effects of price, brand, and store information on buyers' product evaluations. J. Mark. Res. 1991, 28, 307-319.

53. Phillips, W.J.; Asperin, A.; Wolfe, K. Investigating the effect of country image and subjective knowledge on attitudes and behaviors: US upper midwesterners' intentions to consume Korean food and visit Korea. Int. J. Hosp. Manag. 2013, 32, 49-58. [CrossRef] 
54. Han, H.; Hwang, J.; Lee, M.J.; Kim, J. Word-of-mouth, buying, and sacrifice intentions for eco-cruises: Exploring the function of norm activation and value-attitude-behavior. Tour. Manag. 2019, 70, 430-443. [CrossRef]

55. Hultman, M.; Kazeminia, A.; Ghasemi, V. Intentions to visit and willingness to pay premium for ecotourism: The impact of attitude, materialism, and motivation. J. Bus. Res. 2015, 68, 1854-1861. [CrossRef]

56. Dovidio, J.F.; Pagotto, L.; Hebl, M.R. Implicit attitudes and discrimination against people with physical disabilities. In Disability and Aging Discrimination; Springer: New York, NY, USA, 2011; pp. 157-183.

57. Gröschl, S. Presumed incapable: Exploring the validity of negative judgments about persons with disabilities and their employability in hotel operations. Cornell Hosp. Q. 2013, 54, 114-123. [CrossRef]

58. Kaye, H.S.; Jans, L.H.; Jones, E.C. Why don't employers hire and retain workers with disabilities? J. Occup. Rehabil. 2011, 21, 526-536. [CrossRef] [PubMed]

59. Noor, A.A.M.; Manaf, A.R.A.; Isa, M.F.M. Qualities of employees with disabilities in organization: Exploring evidence from Malaysian employers. Int. J. Account. 2018, 3, 32-43.

60. Rosenbaum, M.S.; Baniya, R.; Seger-Guttmann, T. Customer responses towards disabled frontline employees. Int. J. Retail Distrib. Manag. 2017, 45, 385-403. [CrossRef]

61. Kalargyrou, V. Gaining a competitive advantage with disability inclusion initiatives. J. Hum. Res. Hosp. Tour. 2014, 13, 120-145. [CrossRef]

62. Lindsay, S.; Cagliostro, E.; Albarico, M.; Mortaji, N.; Karon, L. A systematic review of the benefits of hiring people with disabilities. J. Occup. Rehabil. 2018, 28, 634-655. [CrossRef]

63. Russell, D.W.; Russell, C.A. Here or there? Consumer reactions to corporate social responsibility initiatives: Egocentric tendencies and their moderators. Mark. Lett. 2010, 21, 65-81. [CrossRef]

64. Hofman, P.S.; Newman, A. The impact of perceived corporate social responsibility on organizational commitment and the moderating role of collectivism and masculinity: Evidence from China. Int. J. Hum. Resour. Manag. 2014, 25, 631-652. [CrossRef]

65. Siperstein, G.N.; Romano, N.; Mohler, A.; Parker, R. A national survey of consumer attitudes towards companies that hire people with disabilities. J. Vocat. Rehabil. 2006, 24, 3-9.

66. Hwang, J.; Hyun, S.S. First-class airline travelers' tendency to seek uniqueness: How does it influence their purchase of expensive tickets? J. Travel Tour. Mark. 2017, 34, 935-947. [CrossRef]

67. Hwang, J.; Lee, J. A strategy for enhancing senior tourists' well-being perception: Focusing on the experience economy. J. Travel Tour. Mark. 2019, 36, 314-329. [CrossRef]

68. Zeithaml, V.A.; Berry, L.L.; Parasuraman, A. The behavioral consequences of service quality. J. Mark. 1996, 60, 31-46. [CrossRef]

69. Hwang, J.; Choi, J.K. An investigation of passengers' psychological benefits from green brands in an environmentally friendly airline context: The moderating role of gender. Sustainability 2018, 10, 80. [CrossRef]

70. Hennig-Thurau, T.; Gwinner, K.P.; Gremler, D.D. Understanding relationship marketing outcomes: An integration of relational benefits and relationship quality. J. Serv. Res. 2002, 4, 230-247. [CrossRef]

71. Hwang, J.; Kim, H. Consequences of a green image of drone food delivery services: The moderating role of gender and age. Bus. Strategy Environ. 2019, 28, 872-884. [CrossRef]

72. Fornell, C.; Larcker, D.F. Evaluating structural equation models with unobservable variables and measurement error. J. Mark. Res. 1981, 18, 39-50. [CrossRef]

73. Bagozzi, R.P.; Yi, Y. On the evaluation of structural equation models. J. Acad. Mark. Sci. 1988, 16, 74-94. [CrossRef]

74. Hair, J.F.; Black, W.C., Jr.; Babin, B.J.; Anderson, R.E.; Tatham, R.L. Multivariate Data Analysis, 6th ed.; Prentice-Hall: Upper Saddle River, NJ, USA, 2006.

75. Byrne, B.M. Structural equation modeling with AMOS, EQS, and LISREL: Comparative approaches to testing for the factorial validity of a measuring instrument. Int. J. Test. 2001, 1, 55-86. [CrossRef]

76. Birth, G.; Illia, L.; Lurati, F.; Zamparini, A. Communicating CSR: Practices among Switzerland's top 300 companies. Corp. Commun. Int. J. 2008, 13, 182-196. [CrossRef]

77. Skard, S.; Thorbjørnsen, H. Is publicity always better than advertising? The role of brand reputation in communicating corporate social responsibility. J. Bus. Ethics 2014, 124, 149-160. [CrossRef]

78. Eberle, D.; Berens, G.; Li, T. The impact of interactive corporate social responsibility communication on corporate reputation. J. Bus. Ethics 2013, 118, 731-746. [CrossRef] 
79. Chevalier, J.A.; Mayzlin, D. The effect of word of mouth on sales: Online book reviews. J. Mark. Res. 2006, 43, 345-354. [CrossRef]

80. Mourali, M.; Laroche, M.; Pons, F. Antecedents of consumer relative preference for interpersonal information sources in pre-purchase search. J. Consum. Behav. Int. Res. Rev. 2005, 4, 307-318. [CrossRef]

(C) 2020 by the authors. Licensee MDPI, Basel, Switzerland. This article is an open access article distributed under the terms and conditions of the Creative Commons Attribution (CC BY) license (http://creativecommons.org/licenses/by/4.0/). 